Dr Maria Tsakeni

University of the Free State

Email: tsakenim@ufs.ac.za

DOI: $h$ ttp://dx.doi.

org/10.18820/2519593X/pie. v35i1.7

ISSN 0258-2236

e-ISSN 2519-593X

Perspectives in Education

2017 35(1): 81-97

(c) UVIUFS

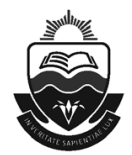

\section{The promotion of sustainable environmental education by the Zimbabwe Ordinary level science syllabi}

\begin{abstract}
Chemical education provides methods and theories that enable learners to understand some environmental issues in their communities better. Following the impetus on education for sustainable development (ESD), green chemistry and the need for learners to use the local place as a springboard to learn and understand global environmental issues, this paper describes the integration of environmental chemistry in an Ordinary level physical science 5009 syllabus. Using a mixed methods approach in the form of a case study of a rural school in the Murewa district of Zimbabwe, data were collected by means of an open-ended questionnaire applied to two science teachers, lesson observations and a posttest only control group design. The findings of the study indicate that the teachers believed that place-based pedagogy involves outdoor and classroom activities such as laboratory experiments, projects, investigations and debates. The place-based activities relevant to the rural school settings were environmental issues around soil and water degradation, toxic chemicals in the environment and fuels for domestic use. The post-test demonstrated the place-based pedagogy was effective for learner achievement, problem-solving and environmental awareness. A recommendation is made for the Ordinary science syllabi to emphasise that place-based approaches to reflect in environmental education for ESD implementation as well as assessment practices.
\end{abstract}

Keywords: Education for sustainable development, green chemistry, environmental chemistry, place-based pedagogy

\section{Introduction}

Creating an environmentally literate citizenry is one of the important goals secondary school education is mandated to achieve (Schild, 2016; Jegstad \& Sinnes, 2015). Environmental education is therefore integrated in the subjects offered in secondary school. The integration of environmental education in the school subjects has philosophical and instructional strategy implications. Of significance is the promotion of sustainable development through environmental chemistry education (Eilks, 2015; Warner \& Elsier, 2015). As a way of tackling challenges of unsustainable social, economic and environmental development through ESD, the Decade of Education for Sustainable Development (DESD) 2005-2014 was 
coordinated at a global level by the United Nations (United Nations, 2002; Dawe, Jucker \& Martin, 2005). Following the above impetus, there are notable efforts in chemistry education to foster ESD (Burmeister \&Eilks, 2012; Eissen, 2012). One significant way of implementing the environmental dimension of ESD has been done through the integration green chemistry principles (Burmeister, Rauch \& Eilks, 2012, Eilks and Rauch, 2012; Karpudewan, Ismail \& Roth, 2012). Green chemistry is based on the 12 principles as propounded by Anastas and Warner, 1998. Summarised, the principles advocate for the prevention of excessive generation of waste, the reduction of excessive consumption of materials including energy and the prevention of the release of hazardous chemicals into the environment (Karpudewan et al., 2012, Garner, Siol \& Eilks, 2015; Warner \& Elsier, 2015). Instructional strategy implications include the use of local place examples as a springboard to understand global environmental issues. The instructional strategy is at the heart of place-based pedagogy and ESD (Davis, 2000).

Given the contribution of chemistry and the chemistry industry to the $21^{\text {st }}$ century environmental challenges, learners should understand and be able to evaluate chemistryrelated processes and products and the manner in which they affect the future (Jegstad \& Sinnes, 2015; Mandler, Mamlok-Naaman, Blonder, Yayon \& Hofstein, 2012). Science education aims to equip learners with the ability to use science knowledge in everyday life by making informed decisions to improve the quality of life (Holbrook, 2009). Environmental issues and concerns are an integral part of everyday life. It has become an imperative of environmental education to inculcate in learners environmentally responsible behaviours (Schild, 2016; Stanisic \& Maksic, 2014). The inculcation of environmentally has implications on the nature of instructional strategies in the science classrooms. One way to ensure that learners begin to develop skills to care for places is the use of placed-based pedagogies in environmental education (Spahiu, Korca \& Lindemann-Mathies, 2014).

Set amidst the global green chemistry and sustainable development initiatives the rural poor in Africa rely on the local natural resources such as forests, land and water for sustenance (Somorin, 2010). Similarly, the livelihoods of populations in Zimbabwean rural areas are intricately connected to their forests, land and water for domestic and agricultural activities. Historically rural areas in Zimbabwe were created as settlement areas for Africans during the colonial era. These areas were agro-ecologically unfavourable and the people were deprived of meaningful livelihoods and banished to ever-deepening conditions of poverty (Thebe, 2012). The areas are overpopulated as people share the available natural resources with their domestic animals. Overpopulation, poor environmental management practices combined with a land tenure system that promotes overgrazing and monoculture are some of the major causes of environmental degradation in the rural areas of Zimbabwe (Chagumbura et al., 2016). Chifamba (2011) suggests that the land use practices have contributed to the hostile changes observed on the hydrological cycle. The hostile changes have in turn resulted in the marked decline in biodiversity, degradation of the soil and water and over exploitation of natural resources (ibid). Zimbabwe is situated in sub-Saharan Africa, which has experienced its fair share of climate change effects in the form of droughts that cripple some of the communities' efforts to ensure food security and poverty alleviation (Frost et al., 2007).

Embracing the ESD initiatives, the teaching and learning of chemistry can be used as a platform and lens for learners in the rural areas to examine some of the environmental degradation phenomena that manifest in their communities. These include water pollution due to the release of phosphates and nitrates into the water sources from agricultural activities. The 
release of phosphates and nitrates is accentuated by stream bank cultivation (Mapira, 2011). The presence of significant amounts of nutrients in water sources is an environmental degradation phenomenon that has provided case studies in science education. The case studies have enabled learners to observe the consequences of this kind of pollution first-hand evidenced by the growth of water hyacinth in the country's major water bodies such as Lake Chivero and Lake Manyame (Chawira, Dube \& Gumindoga, 2013). The agricultural activities also result in the release of synthetic herbicides and pesticides into the environment. Some of the pesticides such as the organophosphates and organochlorides are known to have mammalian toxicity action and low biodegradability, which make them last in the environment longer (Bertolin, Avanani \& Matos, 2013). The farming practices have also resulted in significant soil nutrient depletion and have negative implications of agricultural sustainability.

Environmental education is often associated with the constructivist theory of learning (Kaharan \& Roehrig, 2015; Davis, 2000). Based on the works of Vygotsky (1978) three basic tenets of social constructivism learning can be highlighted which are learning to learn, teachers as facilitators of learning and learning as a social activity (Alt, 2016). Accordingly, learners actively participate and collaborate in the construction of knowledge in authentic environments such as real life situations (Bonk \& Cunningham, 1998). Outdoor education is emphasised through place-based, experiential learning and fieldwork to encourage learners to participate actively in the construction of knowledge when learning about the environment (Makoni, 2013; Spahiu et al., 2014). The integration of ESD requires the nurturing of skills for the care and protection of the environment such as solution finding and multifaceted problem solving in the real world (Warner \& Elsier, 2015). Similarly, there is an increasing integration of green or sustainable chemistry in chemistry education as a way of implementing ESD (Karpudewan et al., 2012; Bertolin et al., 2013; Makoni, 2013; Jegstad \& Sinnes, 2015; Garner, Siol \& Eilks, 2015). The purpose of the study was to develop and implement placebased pedagogy activities for the integration of ESD and green chemistry in the teaching and learning of the environmental chemistry component of the Zimbabwe schools examination council (ZIMSEC) physical science 5009 syllabus in rural settings. Accordingly, the study answered the following sub-research questions,

1. What are the teachers' perceptions of place-based pedagogies for the integration of ESD and green chemistry in environmental chemistry education?

2. What place-based activities for the integration of ESD and green chemistry in environmental chemistry education can be developed in rural school settings?

3. What is the effect of place-based activities on learner-performance, problem-solving and environmental awareness?

\section{Education for sustainable development through green chemistry practices}

The impetus on education for sustainable development has prompted chemical societies to develop operational frameworks such the green or sustainable chemistry as formulated by Anastas and Warner (1998). The frameworks have an ultimate goal of reducing and/or eliminating the generation and release of toxic materials (Garner et al., 2015; Karpudewan, Ismail \& Mohamed, 2011). Burmeister, et al. (2012) mention four ways to integrate green chemistry into chemistry education. Firstly, green chemistry can be adopted in the practice of chemistry laboratory work. Some traditional experiments are being substituted by green 
chemistry experiments. Karpudewan, Ismail and Mohamed (2009) suggest replacing the traditional experiments in which toxic chemicals are used with more environmentally friendly experiments. For example, the cooling and heating curve of naphthalene can be replaced with the heating and cooling curve of lauric acid. Similarly, the traditional rate of reaction experiment with sodium thiosulfate is replaced with the rate of reaction experiment with Vitamin C.

Secondly, sustainability strategies can be added as content in chemistry education (Burmeister et al., 2012). For example, topics such as the fractional distillation of petroleum diesel may be replaced with the production of biodiesel (Karpudewan et al., 2012). The topic on polymers may be replaced with biodegradable polymers just as the synthesis of polymers may be replaced with the synthesis of biodegradable polymers. Thirdly, controversial sustainability issues, which are contained in current societal debates, can be integrated in chemistry education. For example, the ongoing controversy about the use of fossil fuels is one of the issues that were integrated into chemistry education (Burmeister et al., 2012). The sustainability focus is to drive initiatives to develop alternative forms of fuels that are environmentally friendly (Warner \& Elsier, 2015). Fourthly, chemistry education can be integrated in whole school education for sustainable development projects. The projects focus on the curriculum, the school campus and the surroundings as well as interactions with other stakeholders (Warner \& Elsier, 2015). Therefore, classroom activities, teacher-learner interactions, content, class programming, professional development and training among other activities in the school should comply with sustainability requirements.

\section{Place-based education}

The advent of education for sustainable development has generated international interest in the pedagogy of the place. It can also be noted that place-based education is widely used in primary school and employed less in secondary school (Waite, 2013). Place-based education is notably a recommended educational approach for environmental education (Ontong \& le Grage, 2015; Goralnik et al., 2012; Sloan, 2013; Dickinson, 2011; Tsevreni \& Panayotatos, 2011). Davis (2000) underscores the need for learners to understand the environmental issues in their communities as a basis to understand the global environmental issues. The approach pushes learning beyond the confines of the classroom walls as the environment and the surroundings become part of the object and medium in the process of environmental education (Spahiu et al., 2014). The utilisation of the environment and the surroundings is believed to be crucial for the achievement of important educational outcomes.

Current trends in science education have witnessed the inclusion of context-based education, the encompassment of socio-scientific problem solving and decision-making in order to enable citizens to function effectively in the real world (Holbrook, 2009). Additionally, education for sustainable development through science is undergirded by addressing the issues of relevance, practicality and values (ibid). In chemistry education for instance, environmental issues are used as a context in teaching and learning. Some of the topical debates include the use of plastics and the environmental impact of chemical synthesis in organic chemistry as socio-scientific issues integrated in the chemistry content (Eilks \& Rauch, 2012).

There is increased emphasis on the promotion of pro-environmental attitudes and behaviours. Hofstein, Eilks and Bybee (2011) note that traditionally the school science content and accompanying instructional strategies did not provide learners with a basic facility for everyday life because the issues of relevance, practicality and values were not 
addressed. Literature on ESD however reveals that teachers lack the skills and knowledge to implement sustainable education (Garner et al., 2015; Makoni, 2013; Burmeister et al., 2012). Environmental education as integrated in science is an avenue to expand science into the real world (Warner \& Elsier, 2015). Borg et al. (2012) point out that by using traditional instructional methods based on fact transmission teachers assume that learners will consequently display the right environmental actions. However, the emphasis by literature in the preceding discussions on the importance of developing the moral, ethical and value-based dimensions for the care of the environment and sustainable development prompts teachers to reflect on appropriate instructional strategies. A consciousness of sustainable environmental and conservational ethic that include a care for places is believed to be best developed through place-based approaches to education (Ontong \& le Grage, 2015; Dickinson, 2011). In this study, the use of place-based pedagogy to teach environmental chemistry was intended for learners to use the environmental issues in their place as a basis to understand environmental issues in the ZIMSEC physical science 5009 syllabus. One of the syllabus aims is for pupils 'to develop interest in, and participate in, caring for the local and global environment' (ZIMSEC, 2013, p. 3)

\section{Methodology}

In order to use the pedagogy of the place to implement ESD and green chemistry principles in the teaching and learning of the environmental chemistry component of the ZIMSEC physical science 5009 syllabus mixed methods were used through a case study approach. Firstly, two Form $3\left(10^{\text {th }}\right.$ grade $)$ science teachers responded to an open-ended questionnaire. The openended questionnaires generated qualitative data to establish how environmental chemistry was taught in the school and use the teachers' perceptions to generate ways to implement placebased pedagogies. Secondly, a post-test only control group design was used to implement the place-based activities. More qualitative data was collected from lesson observations. In a post-test control group design, there is a random assignment of subjects to the control and experimental groups and a pre-test is not applied (Sousa, Driessrack \& Merdes, 2007). Since the participating learners were from the integrated science, integrated science and biology or biology and physical science electives the overlapping environmental chemistry issues were used in the study. These were global warming, the use of fossil and renewable fuels, eutrophication, acid rain, soil degradation and toxic chemicals in the environment. It is not unusual for researchers to develop learning programmes when studying the implementation of ESD through chemistry education (Karpudewan et al., 2009; Galgano, Loffredo, Sato, Reichardt \& El Seoud, 2012; Sheehan, Schneider \& Desha, 2012).

In line with place-based pedagogy, the experimental group engaged in fieldwork to identify environmental degradation phenomena in the school premises and the surrounding communal land. The objectives of the fieldwork were for the learners to 1) identify environmental degradation phenomena in the school and the surrounding communal land 2 ) identify and explain the causes of the environmental degradation phenomena 3) Suggest ways to rehabilitate the degraded environment and 4) discuss alternative practices by the community that ensure sustainable environmental management. The fieldwork generated the place-based environmental issues that were used to develop place-based activities. In the control group, the teacher used the instructional strategies that the teachers usually use for environmental education that relied on direct transmission of facts. Thirdly, data were collected from post-test applied to the experimental and control groups by means of an achievement 
test, an environmental awareness questionnaire and a performance checklist on a problem solving activity.

\section{Sampling}

Purposive sampling techniques were used to select a school accessible to the researcher in one rural part of Murewa district in Zimbabwe. Convenience sampling techniques were used to select the only two Ordinary level science teachers in the school to participate in this study. Learners were invited to participate in the study from the different science streams in the school. These streams were, integrated science, integrated science/biology and biology/ physical sciences. Science at ordinary level in the school was taught as integrated science, biology and physical sciences (ZIMSEC, 2013, ZIMSEC, 2011a, ZIMSEC, 2011b). From a population of 153 Form 3 science learners 105 were willing to participate in the study. These were constituted by all 35 learners from the biology/physical sciences stream, 25 from the integrated science/biology stream and 45 from the integrated science stream. However, stratified random techniques were used to select a sample of 40 learners in the ratio given by the numbers that were willing to participate that is $35: 25: 45$. Accordingly, 13 learners came from the biology/physical sciences stream, 10 from the integrated science/biology stream and 17 learners from the integrated science stream. Simple random techniques were used to select leaners from each group representative group. The process was repeated in order to assign the 40 learners into the control group and the experimental group. The groups initially had 20 learners each. Of these only 19 learners from the experimental group and 18 learners from the control group were available for the post-test. To ensure that the learners voluntarily participated in the study, the teaching and learning activities were informal and conducted as co-curricular activities from $2 \mathrm{pm}$ to $4 \mathrm{pm}$, three times a week for 3 weeks.

\section{Data analysis}

The qualitative data from the open-ended questionnaires with the two teachers and the observation of the place-based activities were analysed through a mix of directed and inductive content analysis techniques. This was a way of reducing the threats to validity (FinfgeldConnett, 2014). The directed approach to content analysis entailed the organisation of the text data as predetermined by the research questions to elicit the perceptions of the teachers and identifying the place-based activities (Elo \& Kyngas, 2008). The inductive content analysis methods were used to identify opportunities to set the findings of the study from both the qualitative and quantitative data in context of findings from the reviewed literature (FinfgeldConnett, 2014). A t-test based on independent samples was run on the means of the two groups to determine whether the differences were significant.

\section{Post-test}

The post-test applied to the experimental and the control groups consisted of an achievement test, a problem-solving task and an environmental awareness questionnaire. Two teachers who taught the experimental and control group jointly set the achievement test to ensure that it covered the content taught to both groups. Question items were selected from past examination and test papers. For the problem-solving activity, learners were divided into four groups of 4-5 members. Therefore, the control and the experimental groups had four groups each. A performance checklist was used to establish the performance of groups as they engaged in the problem-solving activity. The problem prompted learners to use their 
understanding of implications of using firewood as a fuel for domestic use and design alternative forms of fuel that are more efficient as outlined in Figure 1 below.

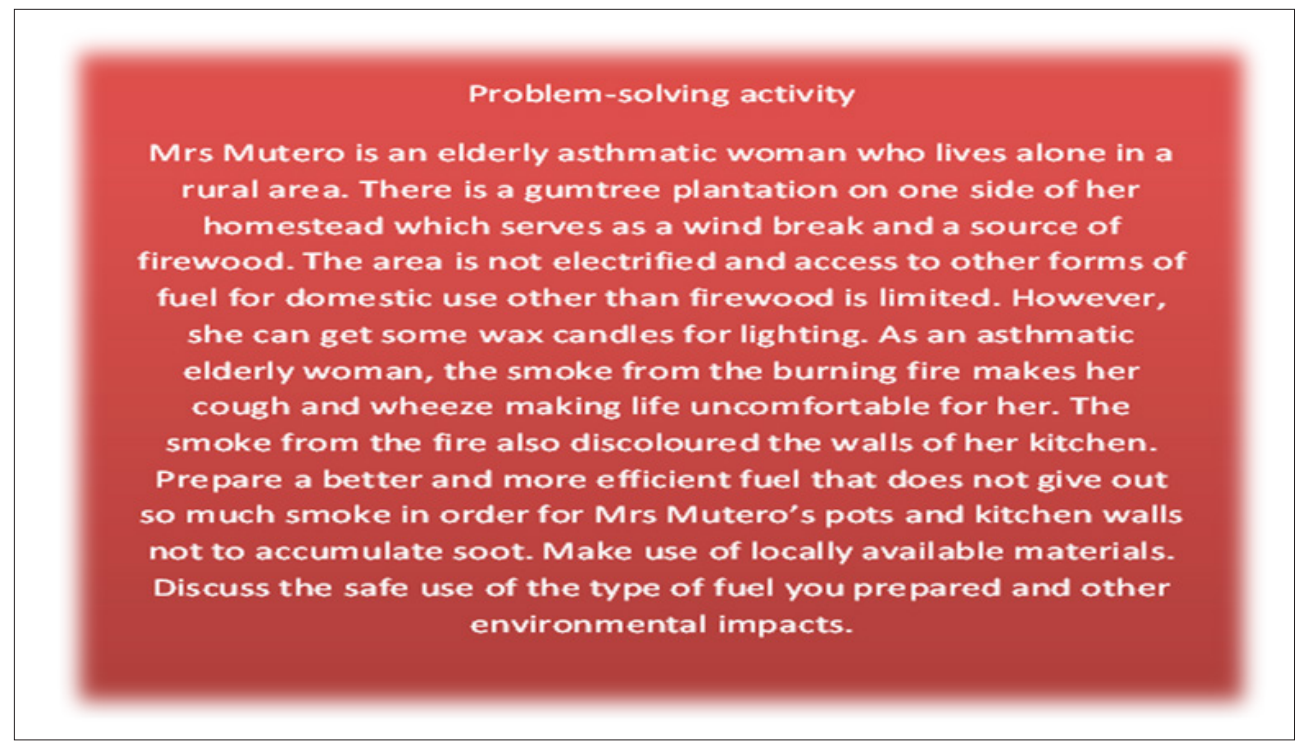

Figure 1: Problem-solving activity

The environmental awareness questionnaire focused on environmental values, ethics and morals. A bar graph to show the response patterns of learners and pie charts to show the performance of learners were used to analyse the results of the environmental awareness questionnaire.

\section{Findings of the study}

The findings are divided in three parts responding directly to the three research questions in this study. Firstly, the teachers' perceptions of place-based pedagogies for the integration of ESD and green chemistry in environmental chemistry education are presented. Secondly, the place-based activities that were developed applying to school rural school settings are presented. Last to be presented are the results of the post-test.

\section{Teachers' perceptions on place-based pedagogy}

The teachers are referred to as Teacher 1 and Teacher 2. The teachers considered field trips, experiments and 'research' (investigations and projects) to be most appropriate for environmental education. However, the teachers conceded that these instructional strategies were not implemented. From what the teachers said it could be deduced that direct transmission methods were commonly used for teaching environmental chemistry. Teachers cited a lack of sufficient time and resources as some of the constraining factors when they considered using some of the instructional strategies. Teacher 1 wrote the following on the open-ended questionnaire in response to a question on the constraints of using some of the instructional strategies, 
They need a lot of time which most teachers do not have. Resources like money for transport for fieldtrips is [are] not available or inadequate. We simply lecture and the syllabus is covered in a short time. Research needs time.

The teachers emphasised the use of experiential learning for environmental chemistry. On being asked to suggest ways of improving the teaching and learning of environmental chemistry Teacher 1 wrote:

(i) Students should be in touch with reality through active involvement that is field trips to sites affected by soil erosion, eutrophication and help in reclamation of these sites.

(ii) Choose sites as case studies or models which really illustrate the effects of toxic chemicals and acid rain to the environment (they [the environmental phenomena] usually happen over time/years of which most pupils will only be involved during the periods they are at school).

Teacher 2 briefly wrote, "Touring industries (heavy) and places like Chinhoyi Caves (erosion) and Lake Chivero (eutrophication)". However, on being asked whether the learners were able to relate the environmental concepts to their everyday lives Teacher 2 simply wrote "Yes" but Teacher 1 was more expressive and wrote,

Yes and no. Concepts such as ozone layer depletion, global warming and acid rain are somehow difficult for them to relate to their everyday life because they happen over a long period of time. The changes are very slow although noticeable. Soil erosion and eutrophication to a certain extent and effects of toxic chemicals, students can relate to their everyday life activities.

The open-ended questionnaire further probed the teachers to give examples of experiential learning activities and the use of projects and investigations as forms of instructional strategies for environmental chemistry education were highlighted. Teacher 2 wrote,

Assigning research to pupils at ' $\mathrm{O}$ ' level on environmental impact locally, use of small groups researching on particular concepts on the environment

In this study, the term 'research' used by the teachers was interpreted as projects and investigations. Teacher 1 gave more examples and wrote,

If students are involved in projects like planting trees, filling of gullies, cleaning of rivers and water sources then they [learners] can find reasons why these activities help improve the environment through interaction with reality and the community.

The teachers' responses highlighted soil and water degradation as one of the place-based environmental issue relevant to the community.

\section{The place-based activities}

The fieldwork culminated in soil and water test activities as laboratory experiments. Additionally, the learners were engaged in a project to observe the effects of nutrients on the growth of water plants in controlled experiments, an investigation to establish the pesticides and herbicides used by the farmers in the area and their impact on the environment and a class debate on the advantages and disadvantages of using fossil fuels. Figure 2 displays details of the activities. 


\section{Soil and water test activities and debate on fuels}

1. Soil tests: In this activity learners were tasked to compare the soil $\mathrm{pH}$ and the presence of nitrates, phosphates, magnesium, calcium and potassium in the soil. The soil samples were collected from six different places which were a nearby well maintained commercial farm, a maize field in the rural area surrounding the school where monoculture was practised, a gumtree plantation, vegetable gardens, a grazing land and an indigenous forest. The learners evaluated the level of soil degradation due to nutrient depletion and $\mathrm{pH}$ levels, if any. The learners were asked to identify the causes of soil degradation in terms nutrient depletion and soil $\mathrm{pH}$ and suggest environmentally friendly soil management practices.

Soil sampling and tests

Each of the six samples was made by collecting five $10 \mathrm{~g}$ samples of soil from the different parts of an area that were mixed together to make a representative sample. The soil was air dried and crushed to make it even. A commercial test kit with colour indicators was used to determine the $\mathrm{pH}$ of the soil and the presence level of nitrates, phosphates and potassium. Additionally, learners determined the acidity and alkalinity of the soil samples by performing the vinegar and the baking soda tests.

2. Water tests: In this activity learners were tasked to compare the $\mathrm{pH}$ of the water and the presence of nitrates, phosphates, magnesium, calcium and potassium in the water samples using the commercial test kit with colour indicators. Five samples of $20 \mathrm{ml}$ each were used. These were distilled water, dam water, river water, shallow well water and borehole water. The learners investigated possible nutrient pollution in the water sources and the causes of the pollution if identified. They also investigated ways of cleaning the polluting nutrients.

3. Effect of fertilisers on the growth of algae: The learners set up 3 troughs of borehole water into which they introduced algae and placed them outside. In trough1 ammonium nitrate fertiliser was added. In trough 2 potassium nitrate fertiliser was added. No fertiliser was added to trough 3 . The learners observed and compared the growth of the algae in the 3 troughs for 3 weeks.

4. Investigation to establish the types of herbicides and pesticides used by farmers in the community: Learners went out to interview farmers and came up with the names of the pesticides and herbicides and further investigated the impact of the substances on the environment and environmentally friendly alternatives that can be used.

5. Debate on on the advantages and disadvantages of the continued use of fossil fuels: Learners were divided in 2 groups. One group motivated for the continued use of fossil fuels whilst the other motivated to discontinue the use of fossil fuels. Learners were given time to prepare their arguments before the debate was conducted. The activity aimed for the learners to gain a deeper understanding of the impact of fossil fuels on the environment.

Figure 2: Place-based lesson plans

\section{Post-test results}

The results of the achievement test, problem-solving task and environmental awareness questionnaire are presented below.

Table 1: Results of the achievement test

\begin{tabular}{|l|c|c|}
\hline & Control group & Experimental group \\
\hline Sample Standard Deviation, s & 23.39 & 26,08 \\
\hline Total Numbers, N & 18 & 19 \\
\hline Sum: & 870 & 940 \\
\hline Mean \%(Average): & 48.33 & 49.47 \\
\hline Median\% & 45 & 55 \\
\hline Mode\% & 45 & 65 \\
\hline
\end{tabular}


The t-test was run on the results of the achievement test using the Excel spreadsheet application as follows:

$\mathrm{H}_{0:} \mu_{1}=\mu_{2}$ (There is no difference between the two means),

$\mathrm{H}_{\mathrm{A}} \mu_{1 \neq} \mu_{2}$ (There is a difference between the two means)

The ( $p$-value) was 0.89 . Since the $p$-value was greater than alpha $(\alpha=0.05)$, we fail to reject $\mathrm{H}_{0}$. This implies that at $5 \%$ level of significance, there is sufficient evidence to suggest that the performance of the learners in the experimental group is comparable to the performance of the learners in the control group, in the achievement test.

Table 2: Performance checklist for the problem-solving task

\begin{tabular}{|l|c|c|}
\hline \multirow{2}{*}{\multicolumn{1}{|c|}{ Category }} & \multicolumn{2}{c|}{ Number of groups able to perform a task } \\
\cline { 2 - 3 } & Control group & Experimental group \\
\hline Asking investigative questions & 0 & 2 \\
\hline Defining the problem & 2 & 4 \\
\hline Debating ideas & 3 & 4 \\
\hline Making predictions & 2 & 4 \\
\hline Accumulation of background information for designs & 2 & 4 \\
\hline Designing experiments & 0 & 3 \\
\hline Collecting data & 1 & 4 \\
\hline Analysing data & 1 & 4 \\
\hline Drawing conclusions & 1 & 3 \\
\hline Communicating ideas and findings & 2 & 4 \\
\hline Creating artefact & 0 & 4 \\
\hline Asking new question & 0 & 1 \\
\hline Total number of tasks performed & $\mathbf{1 4}$ & $\mathbf{4 1}$ \\
\hline
\end{tabular}

The total number of tasks performed by the experimental group of 41 is higher than the mean number of tasks of 14 performed by the control group. The performance checklist suggests that the experimental group was able to perform more problem-solving task than the control group.

Results of the environmental awareness questionnaire

The results of the environmental awareness questionnaire are described below showing learner response patterns including positive and negative awareness distributions. 


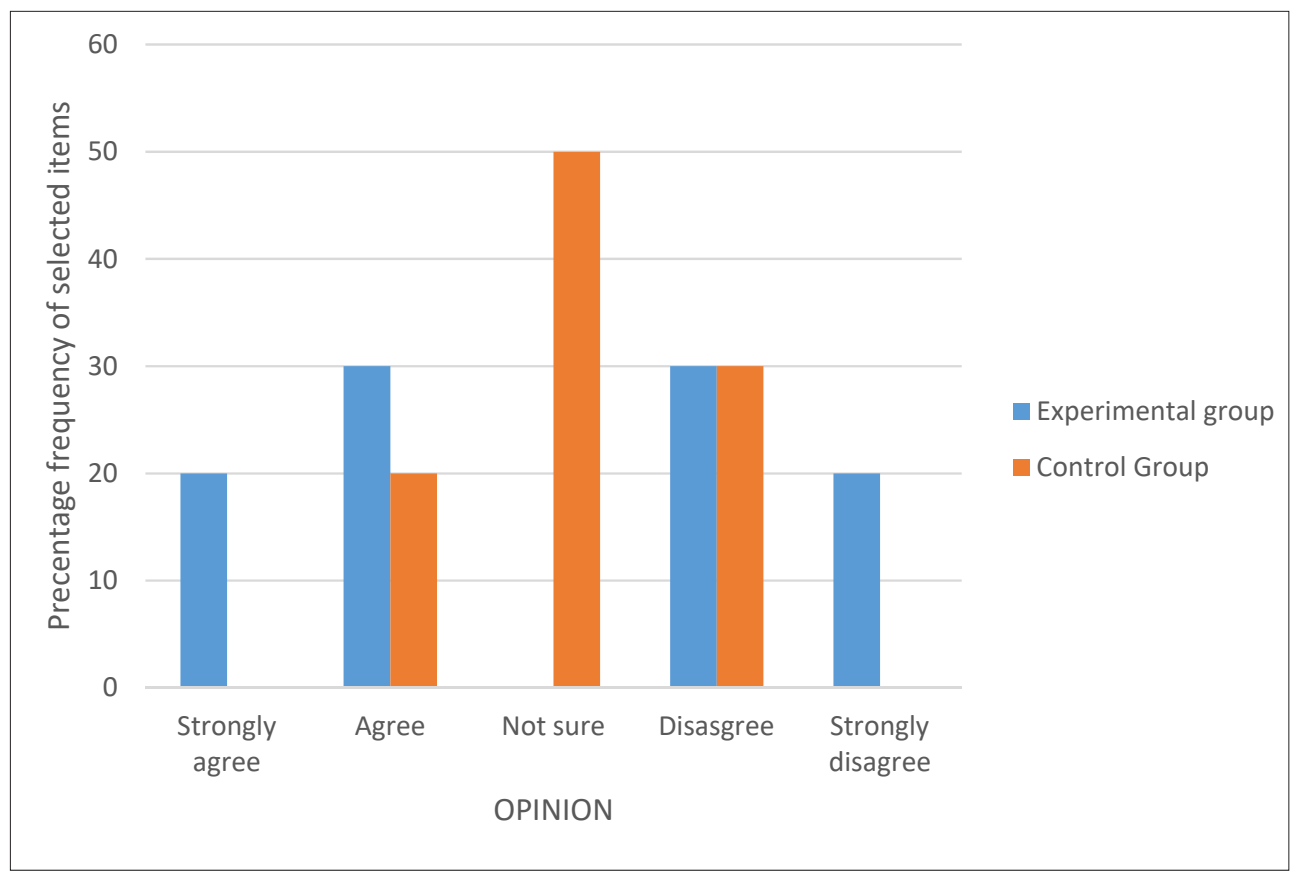

Figure 3: Learners' response patterns

The opinion poll results show how the selection of strongly agree, agree, not sure, disagree and strongly disagree were distributed. What can be noted here is that no learner in the experimental group chose the "not sure" option while the control group had a significant number of learners who chose the "not sure" option. Learners in the experimental group were confident enough to take a position compared to the control group as shown by the first and last bars.

\section{Positive and negative awareness distribution}

The questionnaire was also used to determine the percentage of positive and negative environmental awareness displayed by the learners. The awareness in the questionnaire was measured by the opinions selected on environmental care values, morals and ethics. The experimental group displayed higher positive awareness of $84 \%$ than $61 \%$ displayed by the control group. Below are pie charts that display the positive and the negative awareness distributions. 
Figure 4 a \& b: Learners' awareness

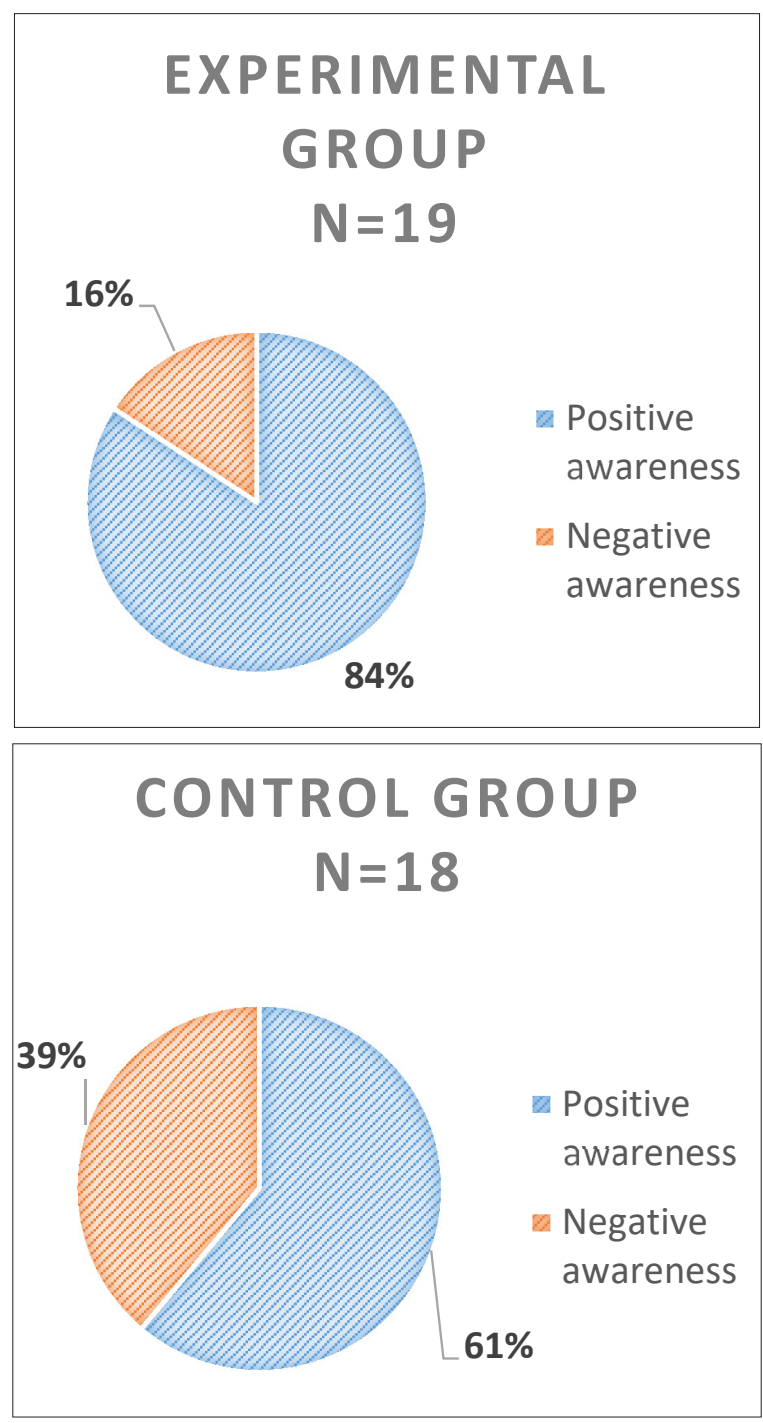

\section{Discussion}

The place-based approach intervention was successful in generating real life situations for the teaching and learning the environmental chemistry component of the syllabus. Authentic learning is one way in which social constructivism addresses issues of relevance and learner interest in school science (Bonk \& Cunningham, 1998). Soil and water degradation, toxic chemicals in the environment and fuels for domestic use were the place-based environmental issues that this case study highlighted for the rural school settings. These environmental issues are closely related to some of the green chemistry principles. The principles include the prevention of excessive generation of waste (water pollution), the reduction of excessive consumption of materials including energy (excessive soil nutrient depletion and firewood 
for domestic use) and the prevention of the release of hazardous chemicals (fertilisers and pesticides) into the environment (Anastas \& Warner, 1998). Chifamba (2011) bemoans the reduction of the quantity and quality of land and water resources in the rural areas of Zimbabwe. The issues are comparable to other global environmental issues such as water quality, the need to conserve natural resources and the impact of the chemical industry on the environment (Holbrook, 2009; Warner \& Elsier, 2015).

Places have characteristic environmental issues that can be used as springboards for learners to develop environmental literacy. It is believed that drives for learners to understand local environmental degradation phenomena are a step to understanding global environmental issues (Davis, 2000; Warner \& Elsier, 2015). The understanding of local environmental issues through place-based pedagogies presents opportunities for learners to develop caring skills for places (Ontong \& le Grage, 2015; Dickinson, 2011; Spahiu et al., 2014). The development of caring skills for the environment is a mandate of ESD. ESD defines sustainable development as one in which young people will be able to act responsibly for themselves and for generations to come in sustainable ways (Burmeister et al., 2012). The care of the local and global environment is embodied in the aims of the ZIMSEC physical science 5009 syllabus (ZIMSEC, 2013).

The achievement test results for the control group and the experimental groups were comparable despite the use of different pedagogical approaches. Transmission of factual and procedural knowledge that heavily rely on the use of textbooks and worksheets are known for ensuring enhanced learner performance in achievement tests (Reid \& Shah, 2007). Based on the findings in this study it is concluded that the place-based approaches are also good at preparing learners for achievement tests. Karpudewan et al. (2012) demonstrated that when green chemistry and sustainable development principles were integrated in instructional strategies, students' performance in achievement tests improved. The experimental group however, outperformed the control group in the problem-solving activity and the environmental awareness questionnaire suggesting that place-based approaches better prepare learners for problem-solving. Ramnarain (2014) contends that pen and paper tests lack validity for assessing inquiry-based skills. The place-based activities were inquiry-based. This paper recommends that assessment practices should be made to align with experiential approaches such as place-based and inquiry-based pedagogies. The finding that the experimental group demonstrated a higher environmental awareness than the control is supported by the finding made by Karpudewan et al. (2009) that green chemistry curriculum positively impact on environmental awareness levels of students. Integration of green chemistry is a way to foster ESD (Burmeister et al., 2012; Eissen, 2012; Karpudewan et al., 2012; Hartwell, 2012).

The development of an environmental facility in learners that ensures sustainable development is overly emphasised in the wake of environmental issues in the $21^{\text {st }}$ century (Schild, 2016). Secondary school science syllabi are increasingly reflecting this century's environmental issues as part of the content (Makoni, 2013). However, teaching for sustainable development remains a farce in most science classrooms for various reasons (Borg et al., 2012). The science teachers in this study had knowledge of what research findings recommend as appropriate instructional strategies for environmental education. However, they conceded that they usually aim to transmit the environmental facts to the learners. Additionally, Abdullah, Halim and Shahali (2011) point out that current science curriculum treat environmental knowledge shallowly. Based on the above-mentioned barriers to effective 
environmental education teachers are charged with planning meaningful learning experiences through approaches such as place-based pedagogy to effectively implement ESD.

\section{Conclusion}

The paper sought to describe a place-based approach to implement ESD and green chemistry in the teaching and learning of the environmental chemistry component of the ZIMSEC physical science 5009 syllabus in rural settings. One fundamental principle of sustainable education is the learning of science concepts in order to gain a facility to understand and participate in socioscientific debates within the communities (Holbrook, 2009). The place-based environmental issues identified were around soil and water degradation, the release of toxic chemicals in the environment and types of fuels for domestic use. The issues were in line with some of the green chemistry principles by Anastas and Warner (1998) concerning prevention of pollution, designing for degradation, use of renewable feedbacks and conservation of materials. Learners were able to engage the environmental issues in their community and learn chemistry at the same time. However, ESD relies on pedagogical strategies that are learner-centred and target habits of the mind as mediated by teacher facilitation (Karahan \& Roehrig, 2015). The paper recommends the use of multi-dimensional approaches including place-based approaches to cater for the moral, ethical and behavioural aspects of environmental literacy. The placebased approach can also be used as a context to assess critical skills such as solution finding and problem solving in the care of the environment.

\section{References}

Abdullah, S.I.S.S., Halim, L. \& Shahali, E.H.M. 2011. Integration of environmental knowledge across biology, physics and chemistry subjects at secondary school level in Malaysia. Procedia Social and Behavioural Sciences, 15, 1024-1028. https://doi.org/10.1016/j.sbspro.2011.03.233

Alt, D. 2016. Students' perceived constructivist learning environment: Empirical examples of the comparison between facet theory with smallest space analysis and confirmatory factor analysis. European Journal of Psychological Assessment. Available at http://dx.doi. org/10.1027/1015-5759/a000358 [Accessed 22 January 2017]

Bertolin, R., Avanani, M. \& Matos, A. 2013. Using green chemistry in teaching. A Brazilian case study. Chemistry International, 10-11.

Bonk, C. J., \& Cunningham, D. J. 1998. Searching for learner-centered, constructivist, and sociocultural components of collaborative educational learning tools. Electronic collaborators: Learner-centered technologies for literacy, apprenticeship, and discourse, 25, 25-50.

Borg, C., Gericke, N., Holgund, H.O. \& Bergman, E. 2012. The barriers encountered by teachers implementing for sustainable development: Discipline bound differences and teaching traditions. Research in Science and Technological Education, 30(2), 185-207. https:// doi.org/10.1080/02635143.2012.699891

Burmeister, M., Rauch, F., \& Eilks, I. 2012. Education for sustainable development (ESD) and chemistry education. Chemistry Education Research and Practice, 13, 59-68. https://doi. org/10.1039/C1RP90060A

Chagumbura, C., Rurinda, J., Nezomba, H., Mtambanengwe, F., \& Mapfumo, P. 2016. Use patterns of natural resources supporting livelihoods of smallholder communities and implications for climate change adaptation in Zimbabwe. Environment, Development and Sustainability, 18(1), 237-255. https://doi.org/10.1007/s10668-015-9637-y 
Chawira, M., Dube, T. \& Gumindoga, W. 2013. Remote sensing based water quality monitoring in Chivero and Manyame Lakes of Zimbabwe. Physics and Chemistry of the Earth, 66, 38-44. https://doi.org/10.1016/j.pce.2013.09.003

Chifamba, E. 2011. Integrated watershed management for minimising land degradation and enhancing livelihoods of resource poor farmers. A case of Pungwe River watershed, Zimbabwe. Journal of Sustainable Development in Africa, 13(8), 107-119.

Davis, G.R. 2000. Standards-based education and its impacts on environmental science education. Electronic Journal of Science Education, 4(3), online. Available at eric. ed.gov/?id=EJ651180 [Accessed 12 May 2016].

Dawe, G., Jucker, R. \& Martin, S. 2005. Sustainable development in higher education: Current practice and future developments. The Higher Education Academy. Available at https://www. heacademy.ac.uk/resources/sustainable-development-higher-eduaction-current-practiceand-future-development\#comments-0 [Accessed 28 July 2016].

Dickinson, E. 2011. Displaced in nature: The cultural production of (non-)place in place-based forest conservation pedagogy. Environmental Communication, 5(3), 300-319. https://doi.org/ 10.1080/17524032.2011.584889

Eilks, I. (2015). Science education and education for sustainable development - Justifications, models, practices and perspectives. Eurasia Journal of Mathematics, Science \& Technology Education, 11(1), 149-158.

Eilks, I. \& Rauch, F. 2012. Sustainable development and green chemistry in chemistry education. Chemistry Education Research and Practice, 13, 57-58. https://doi.org/10.1039/ C2RP90003C

Eissen, M. 2012. Sustainable production of chemicals- an educational perspective. Chemistry Education Research and Practice, 13, 103-111. https://doi.org/10.1039/C2RP90002E

Frost, P., Campbell, B., Luckert, M., Mutamba, M. \& Mandondo, A. 2007. In search of improved rural livelihoods in semi-arid regions through local management of natural resources: Lessons from case studies in Zimbabwe. World Development, 35(11), 1961-1974. https://doi. org/10.1016/j.worlddev.2006.11.012

Garner, N., Siol, A. \& Eilks, I. 2015. The potential of non-formal laboratory environments for innovating the chemistry curriculum and promoting secondary school level students education for sustainability. Sustainability, 7, 1798-1818. https://doi.org/10.3390/su7021798

Goralnik, L., Millenbah, K.F., Nelson, M.P. \& Thorp, L. 2012. An environmental pedagogy of care: Emotion, relationships, and experience in Higher Education ethics learning. Journal of Experiential Education, 35(3), 412-428. https://doi.org/10.1177/105382591203500303

Hofstein, A., Eilks, I. \& Bybee, R. 2011. Societal issues and their importance for contemporary science education- A pedagogical justification and the state-of-the-art in Israel, Germany and the USA. International Journal of Science and Mathematics Education, 9, 1459-1483. https:// doi.org/10.1007/s10763-010-9273-9

Holbrook, J. 2009. Meeting challenges to sustainable development through science and technology education. Science Education International, 20(1/2), 44-59.

Jegstad, K.M. \& Sinnes, A.T. 2015. Chemistry teaching for the future: A model for secondary chemistry education for sustainable development. International Journal of Science Education, 37(4), 655-683. https://doi.org/10.1080/09500693.2014.1003988 
Kaharan, E. \& Roehrig, G. 2015. Constructing media artefacts in a social constructivist environment to enhance students' environmental awareness and activism. Education and Technology, 24(1), 103-118.

Karpudewan, M., Ismail, Z.H. \& Mohamed, N. 2009. The integration of green chemistry experiments with sustainable development concepts in the pre-service teachers' curriculum. Experiences from Malaysia. International Journal of Sustainability in Higher Education, 10(2), 118-135. https://doi.org/10.1108/14676370910945936

Karpudewan, M., Ismail, Z. \& Mohamed, N. 2011. Greening a chemistry teaching methods course at the school of educational studies, Universiti Sains Malaysia. Journal of Education for Sustainable Development, 5(2): 197-214. https://doi.org/10.1177/097340821100500210

Karpudewan, M., Ismail, Z. \& Roth, W.M. 2012. Promoting pro-environmental attitudes and reported behaviours of Malaysian pre-service teachers using green chemistry experiments. Environmental Education Research, 18(3), 375-389. https://doi.org/10.1080/13504622.2011. 622841

Makoni, M. 2013. Environmental education in Zimbabwean secondary schools: Greening or transformative social change? International Journal of Asian Social Science, 3(4), 971-991.

Mandler, D., Mamlok-Naaman, R., Blonder, R., Yayon, M \& Hofstein, A. 2012. High-school chemistry teaching through environmentally oriented curricula. Chemistry Education Research and Practice, 13, 80-92. https://doi.org/10.1039/C1RP90071D

Mapira, J. 2011. River pollution in the city of Mutare (Zimbabwe) and its implications for sustainable development. Journal of Sustainable Development in Africa, 13(6), 181-194.

Ontong, K. \& le Grage, L. 2015. The need for place-based education in South African schools: The case of Greenfields Primary. Perspectives in Education, 33(3), 42-57.

Ramnarain, U.D. 2014. Questioning the validity of inquiry assessment in a high stakes physical sciences examination. Perspectives in Education, 32(1), 179-191.

Reid, N. \& Shah, I. 2007. The role of laboratory work in university chemistry. Chemistry Education Research and Practice, 8(2), 172-185. https://doi.org/10.1039/B5RP90026C

Schild, R. 2016. Environmental citizenship: What can political theory contribute to environmental education practice? The Journal of Environmental Education, 47(1), 19-34. https://doi.org/10 $.1080 / 00958964.2015 .1092417$

Sloan, C. 2013. Transforming multicultural classrooms through creative place-based learning. Multicultural Education, 21(1), 26-32.

Somorin, O.A. 2010. Climate impacts forest-dependent rural livelihoods and adaption strategies in Africa: A review. African Journal of Environmental Science and Technology, 4(13), 903-912.

Sousa, V.D., Driessack, M. \& Merdes, A.C. 2007. An overview of research designs relevant to nursing part1: Quantitative research designs. Revista Latino-American de Enfermagem, 15(3), 502-507. https://doi.org/10.1590/S0104-11692007000300022

Spahiu, M.H., Korca, B. \& Lindemann-Mathies, P. 2014. Environmental education in high schools in Kosovo - A teachers' perspective. International Journal of Science Education, 36(16), 2750-2771. https://doi.org/10.1080/09500693.2014.933366 
Stanisic, J. \& Maksic, S. 2014. Environmental education in Serbian primary schools: Challenges and changes in curriculum pedagogy and teacher training. The Journal of Environmental Education, 45(2), 118-131. https://doi.org/10.1080/00958964.2013.829019

Thebe, V. 2012. 'New realities' and tenure reforms: Land use in worker-peasant communities of south-western Zimbabwe (1940s-2006). Journal of Contemporary African Studies, 1, 99117. https://doi.org/10.1080/02589001.2011.601043

Tsevreni, I. \& Panayotatos, E. 2011. Participatory creation of a place-based teaching and learning methodology for children's participation and citizenship in the urban environment. Children, Youth and Environment, 21(1), 293-309.

United Nations (UN). 2002. Resolution 57/254. United Nations Decade of Education for Sustainable Development (57/254). Available at http://www.un.documents.net/a57r254.htm [Accessed 25 May 2016].

Vygotsky, L.S. 1978. Mind and society: The development of higher mental processes. Cambridge, MA: Harvard University Press.

Waite, S. 2013. 'Knowing your place in the world': How place and culture support and obstruct educational aims. Cambridge Journal of Education, 43(4), 413-433. https://doi.org/10.1080/0 305764X.2013.792787

Warner, B.P \& Elsier, M. 2015. How do sustainable schools integrate sustainability education? An assessment of certified K-12 schools in the United States. The Journal of Environmental Education, 46(1), 1-22. https://doi.org/10.1080/00958964.2014.953020

Zimbabwe School Examinations Council (ZIMSEC). (2011a). Ordinary Level Syllabus Biology (5008). Harare: ZIMSEC.

Zimbabwe School Examinations Council (ZIMSEC). (2011b). Ordinary Level Syllabus Integrated Science (5006). Harare: ZIMSEC.

Zimbabwe School Examinations Council (ZIMSEC). (2013). Ordinary Level Syllabus Physical Science (5009). Harare: ZIMSEC. 